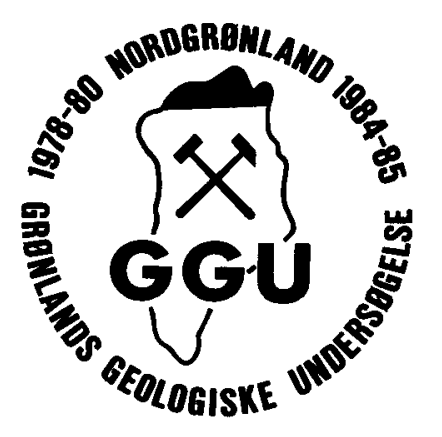

\title{
Reconnaissance scale geochemical survey in central and western North Greenland. Preliminary results concerning zinc and barium
}

\author{
Agnete Steenfelt
}

\begin{abstract}
Stream sediment samples were collected at a density of 1 sample per $30 \mathrm{~km}^{2}$ in Warming Land, Wulff Land, Nares Land, Nansen Land and along Navarana Fjord. The minus $0.1 \mathrm{~mm}$ grain size fraction of the samples was analysed by $\mathrm{X}$-ray fluorescence for 30 elements. The regional distribution pattern for the contents of $\mathrm{Zn}$ and $\mathrm{Ba}$ reflects the lithological changes. Lowest values for both elements occur in the lower Palaeozoic carbonate platform and the contents gradually increase northwards in the flysch deposits of the Silurian basin to a high level for both elements in samples from the folded Cambrian basin deposits in Nansen Land. Anomalously high values of $\mathrm{Zn}$ and Ba at Navarana Fjord and at north-west Nares Land are associated with a thin Cambro-Ordovician unit of black dolomitic mudstones. Reconnaissance zinc anomalies and the occurrence of massive sphalerite in the matrix of a breccia zone at Navarana Fjord are taken as indications of a major zinc mineralising event.
\end{abstract}

A. S., Grønlands Geologiske Undersøgelse, Øster Voldgade 10, DK-1350 Copenhagen K, Denmark.

The geochemical exploration programme for North Greenland 1984 comprised a low density (1 sample per $30 \mathrm{~km}^{2}$ ) stream sediment survey covering $13000 \mathrm{~km}^{2}$ (exclusive of ice caps and lakes). A limited number of rock samples, heavy mineral concentrates, soil samples and plant samples were also collected. The aim of the stream sediment survey, which will be continued in 1985, is to outline large geochemical provinces and give an indication of possible mineralised districts within the area covered by the North Greenland mapping programme 1984-1985.

The area covered (fig. 1) consists of three major tectonic - stratigraphic units (Henriksen, 1985, fig. 1): (1) Precambrian crystalline basement exposed in a small area at the head of the fiord separating Wulff Land and Nares Land, (2) Cambrian-Silurian carbonate platform deposits in an east-west belt to the south, and (3) Cambrian-Silurian clastic deep-water sediments to the north. The latter is involved in the Upper Palaeozoic North Greenland fold belt in its northernmost part. 


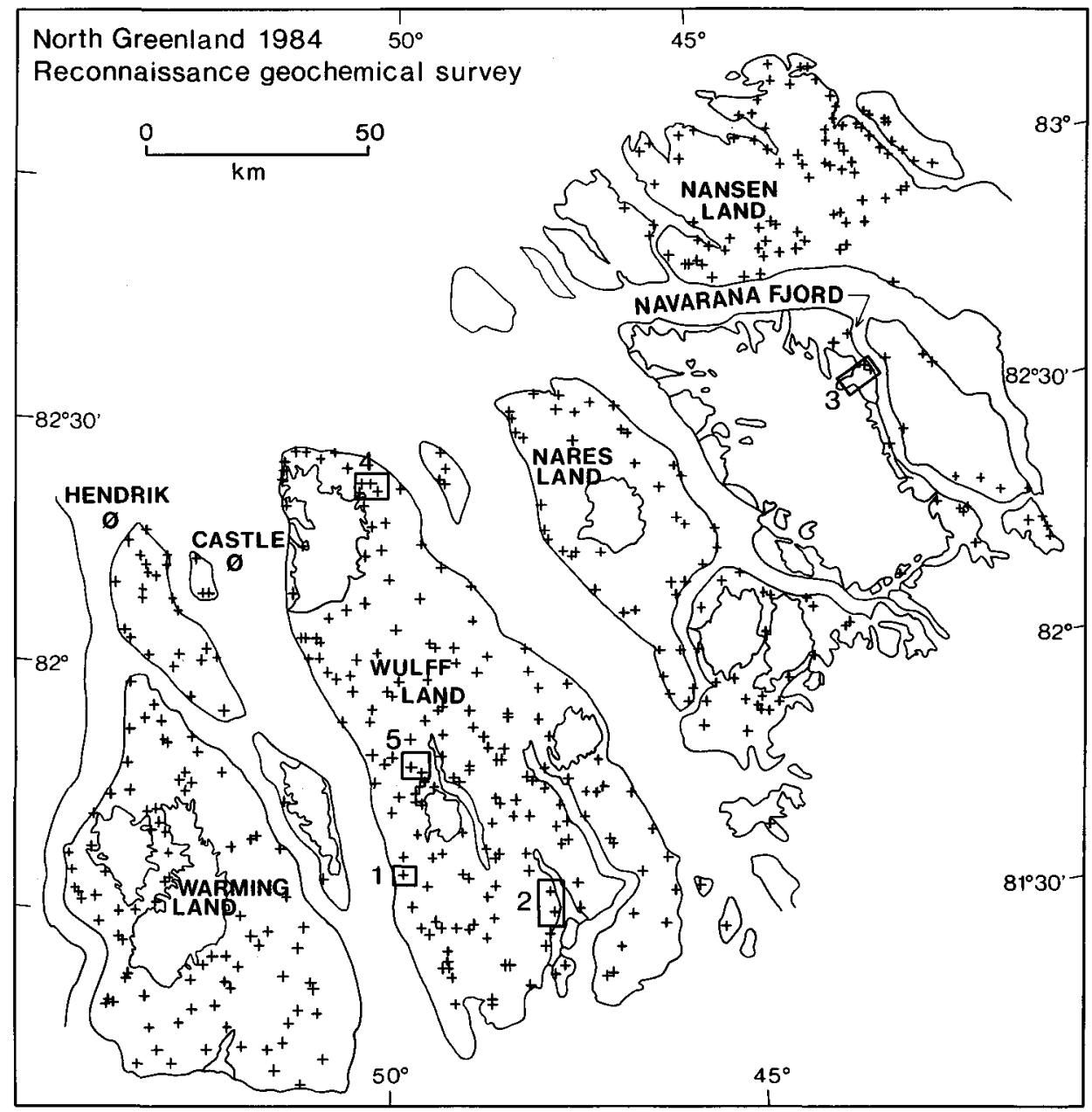

Fig. 1. Distribution of sample sites in the reconnaissance stream sediment survey. The numbered squares show the location of areas in which streams were sampled in detail.

\section{Sampling and analyses}

The low density sampling of stream sediments was carried out by a two-man team with helicopter support. At each site 300-500 g stream sediment (silt and sand) was collected from 5 to 10 different places in the stream bed over a distance of 10 to $50 \mathrm{~m}$. Duplicate samples were taken at $10 \%$ of the sites.

The conditions for sampling were only optimal from the beginning of July to the beginning of August, i.e. the period when streams are not covered by snow and when transport and deposition of sediment take place.

The drainage pattern is very regular in the fold belt (Nansen Land), and there an even 
coverage of sample sites was obtained. Broad glacial valleys and glaciofluvial plains in the flysch belt (northern Warming Land, Wulff Land and Nares Land) are unsuitable for sampling and the distribution of sample sites was accordingly less even. In the platform region in the south the sample sites are rather evenly distributed, but the catchment areas above the sample site vary considerably in size i.e. are small $\left(1-2 \mathrm{~km}^{2}\right)$ for the streams draining the edges of the plateaus, and larger $\left(10-15 \mathrm{~km}^{2}\right)$ for the systems which have cut deeply into the flat-lying rocks. The drainage systems on the moraine covered plateaus are weakly developed and suitable sample sites are difficult to find.

In southern Warming Land and southern Wulff Land some relatively broad glacially eroded valleys could not be sampled because the valley bottoms are covered by boulders and proper stream beds are lacking.

During the 1984 field season 459 localities were sampled at an average sampling density of 1 sample per $30 \mathrm{~km}^{2}$. Fig. 1 shows the distribution of sample points.

Sampling of stream sediment at short intervals along streams was carried out from camps with the purpose of studying the variability of the chemical composition of the stream sed-

\section{Table 1. Main geological features of the areas sampled in detail}

The location of camps is shown in fig. 1. $\mathrm{C}=$ Cambrian, $\mathrm{C}-\mathrm{O}=\mathrm{Cambro-Ordovician,} \mathrm{S}=$ Silurian, seq. = sequence. ${ }^{1}$ Sønderholm \& Due (1985), ${ }^{2}$ Bryant \& Smith (1985), ${ }^{3}$ Peel \& Wright (1985), ${ }^{4}$ Higgins \& Soper (1985).

\begin{tabular}{|c|c|c|c|}
\hline & & $\begin{array}{l}\text { Stratigraphic sequence } \\
\text { within sampled } \\
\text { drainage system }\end{array}$ & Main lithology \\
\hline $\begin{array}{c}\text { CAMP } \\
1\end{array}$ & 0 & $\begin{array}{l}\text { Gonioceras Bay Formation' } \\
\text { Cape Webster Formation' } \\
\text { Nunatami Formation } 1 \\
\text { Permin Land Formation }{ }^{2} \\
\end{array}$ & $\begin{array}{l}\text { Dark grey, limonite stained, cliff forming dolomite } \\
\text { Light, recessive dolomite and limestone } \\
\text { Dark brown, cliff forming dolomite } \\
\text { White, rust coated sandstone }\end{array}$ \\
\hline $\begin{array}{c}\text { CAMP } \\
2\end{array}$ & C & Ryder Gletscher Group ${ }^{3}$ & $\begin{array}{l}\text { Massive to drusy and banded, cliff forming, light co- } \\
\text { loured dolomites } \\
\text { Laminated, dark coloured dolomites } \\
\text { Dark shales } \\
\text { Bituminous, black sandstone } \\
\text { Light coloured sandstone }\end{array}$ \\
\hline CAMP & $\mathrm{C}-\mathrm{O}$ & $\begin{array}{l}\text { Un-named starved basin } \\
\text { seq.4 } \\
\text { Buen Formation } \\
\text { Portfjeld Formation } \\
\text { Sub-Portfjeld sequence }\end{array}$ & $\begin{array}{l}\text { Black dolomitic mudstone with conglomerate bands } \\
\text { Shale } \\
\text { Laminated, banded, dark dolomite } \\
\text { Blocky, massive, grey dolomite } \\
\text { Sandstone/quartzite }\end{array}$ \\
\hline$\underset{4}{\text { CAMP }}$ & $\mathrm{C}-\mathrm{O}$ & $\begin{array}{l}\text { Un-named starved basin } \\
\text { seq.4 } \\
\text { Buen Formation }{ }^{3} \\
\text { Portfjeld Formation } \\
\text { Sub-Portfjeld sequence } \\
\text { Su }\end{array}$ & $\begin{array}{l}\text { Black shales with conglomerate bands } \\
\text { Shales } \\
\text { Dolomites } \\
\text { Sandstone } \\
\text { Black shale }\end{array}$ \\
\hline $\begin{array}{c}\text { CAMP } \\
5\end{array}$ & $S$ & Aleqatsiaq Fjord Formation & $\begin{array}{l}\text { Massive to banded, light coloured limestone } \\
\text { Laminated, dark calcareous mudstone }\end{array}$ \\
\hline
\end{tabular}

7 Rapport nr. 126 


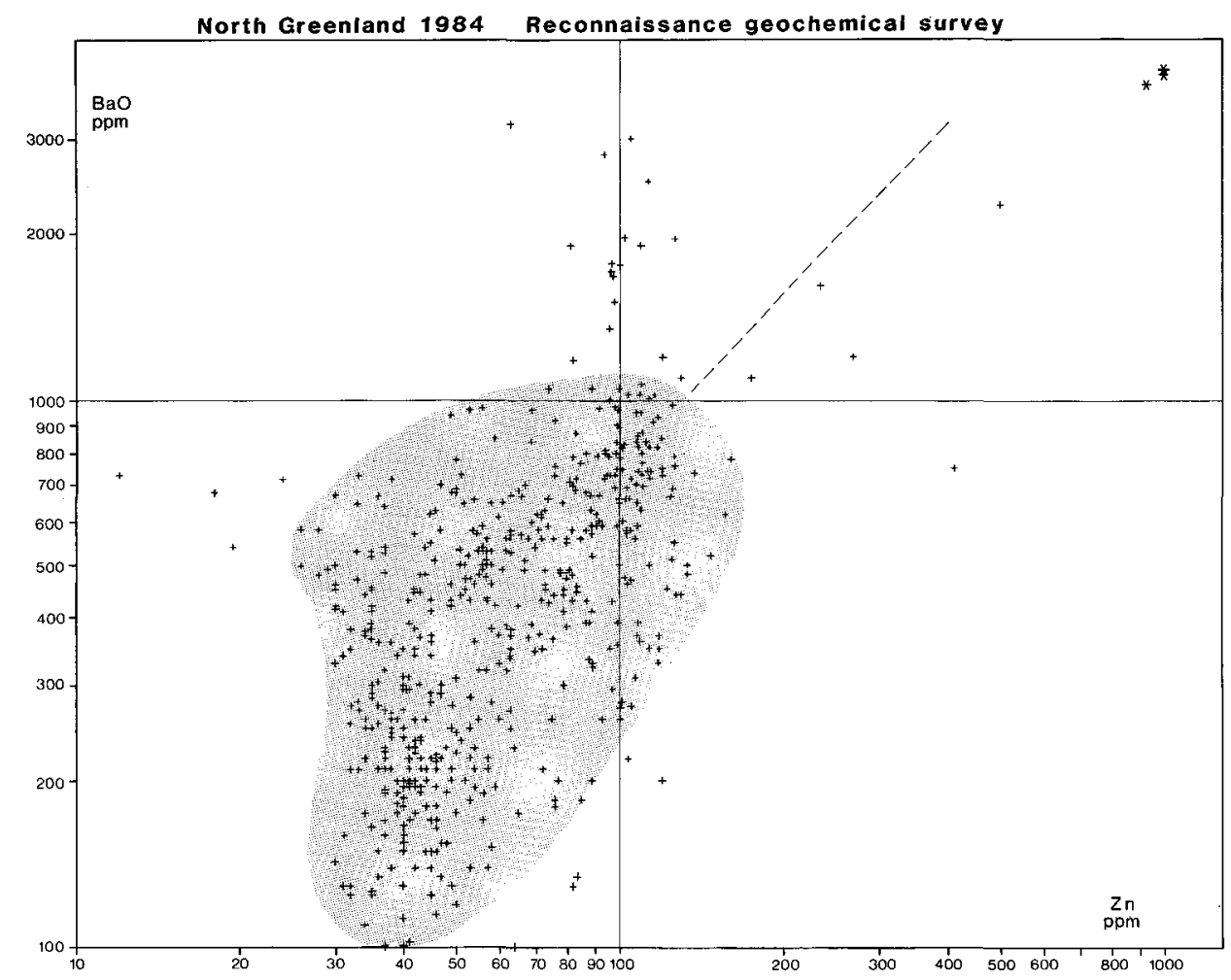

Fig. 2. The concentration of $\mathrm{Zn}$ and $\mathrm{Ba}$ in the $<0.1 \mathrm{~mm}$ grain size fraction of stream sediment. The shaded field comprises the geochemical background variation with respect to $\mathrm{Ba}$ and $\mathrm{Zn}$. The dashed line separates two kinds of anomalous samples, one with Ba-enrichment and the other with enrichment in $\mathrm{Zn}$ and $\mathrm{Ba}$. The asterisks in the upper right corner of the diagram indicate the position of the samples with the highest concentration of $\mathrm{Zn}$ and Ba collected from camp 3.

iment in a local area. The camps were situated in different geological environments as seen from Table 1. The results from the detailed sampling are used to support the evaluation of the data from the reconnaissance survey.

A total of 538 samples from the low density survey and 126 samples from the detailed sampling were sent to Sveriges Geologiska $\mathrm{AB}$ for dry sieving and XRF analysis of the minus 0.1 $\mathrm{mm}$ fraction for the elements $\mathrm{Al}, \mathrm{Ca}, \mathrm{Fe}, \mathrm{K}, \mathrm{Mg}, \mathrm{Mn}, \mathrm{Na}, \mathrm{P}, \mathrm{Si}, \mathrm{Ti}, \mathrm{As}, \mathrm{Ba}, \mathrm{Cl}, \mathrm{Co}, \mathrm{Cr}, \mathrm{Cu}$, Mo, Nb, Ni, Pb, Rb, S, Sn, Sr, Th, V, W, Y, Zn, Zr. The samples of rocks, soil, plants and heavy mineral concentrates have not yet been analysed.

\section{Results and discussion}

At the present stage the analytical data of the stream sediment samples are awaiting computer treatment. The results concerning zinc and barium are presented and discussed here as a preliminary evaluation of the geochemical data. 


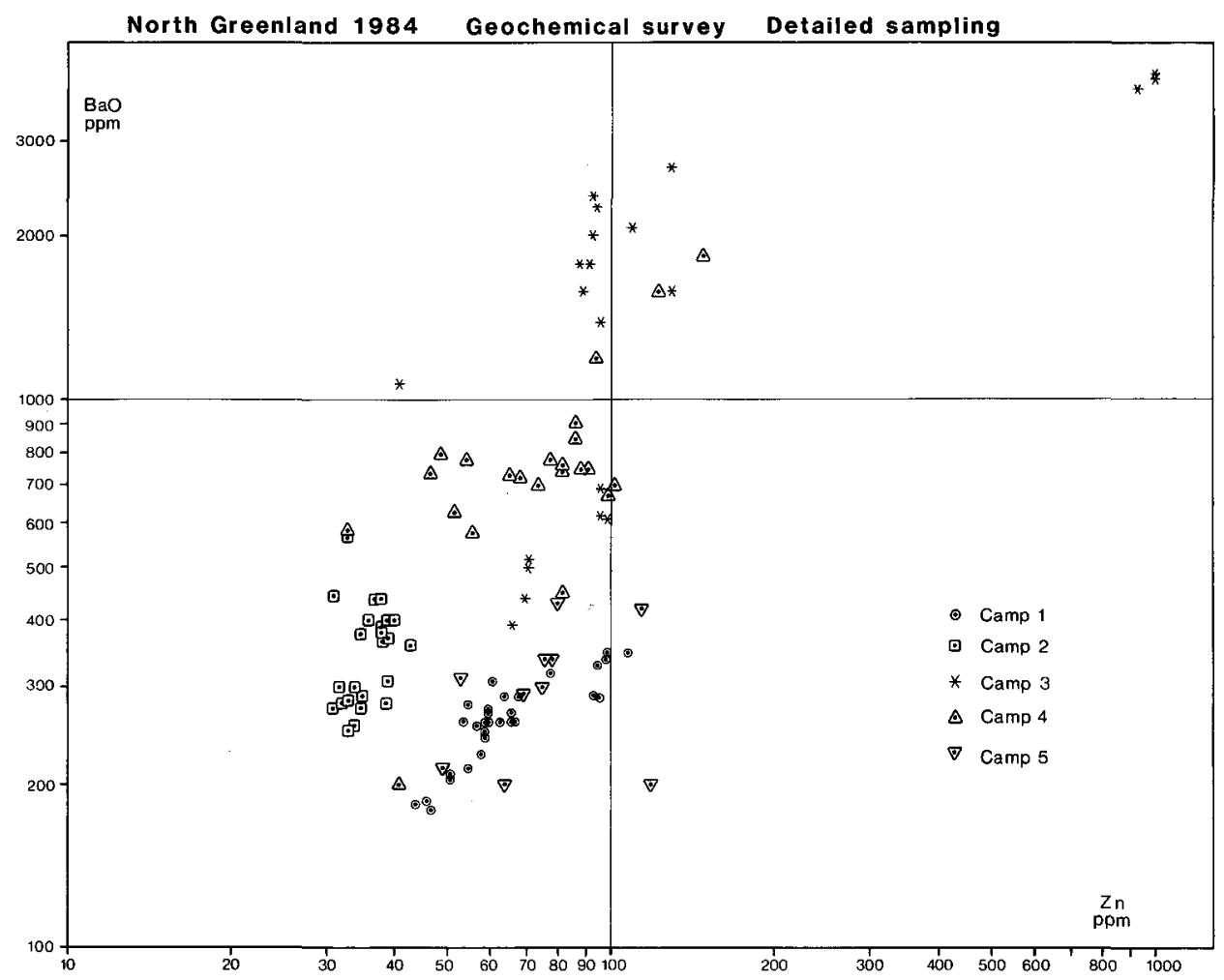

Fig. 3. The concentration of $\mathrm{Zn}$ and $\mathrm{Ba}$ in the $<0.1 \mathrm{~mm}$ grain size fraction of stream sediment.

The concentrations of zinc and barium in the samples from the reconnaissance survey and from the detailed sampling are shown by figs $2 \& 3$, respectively, in which $\mathrm{BaO}$ ppm is plotted against $\mathrm{Zn}$ ppm. (The analysing laboratory reports $\mathrm{BaO}$ concentrations.) In the reconnaissance survey (fig. 2), most of the samples plot within the field of less than c. $1000 \mathrm{ppm} \mathrm{BaO}$ and $120 \mathrm{ppm} \mathrm{Zn}$. In this preliminary evaluation (concerning only zinc and barium) the values lying within the shaded area are considered to represent the regional geochemical background variation and those lying outside this field are termed anomalous.

\section{Geochemical background}

The $\mathrm{Zn}$ and $\mathrm{BaO}$ concentrations plotted on maps show that the variation in geochemical background is closely associated with changes in lithology (see fig. 1 in Henriksen, 1985). This is illustrated by figs $4 \& 5$, in which the division into concentration intervals is kept at a minimum for the sake of simplicity.

In general terms the basement and lower Cambrian, mainly clastic, platform sequences (Portfjeld Formation and Buen Formation) are characterised by very low $\mathrm{Zn}$ content and medium $\mathrm{BaO}$ content. This is confirmed by the analytical results of the detailed sampling from camp 2 (squares in fig. 3). The Ordovician carbonate sequence in the platform has low 


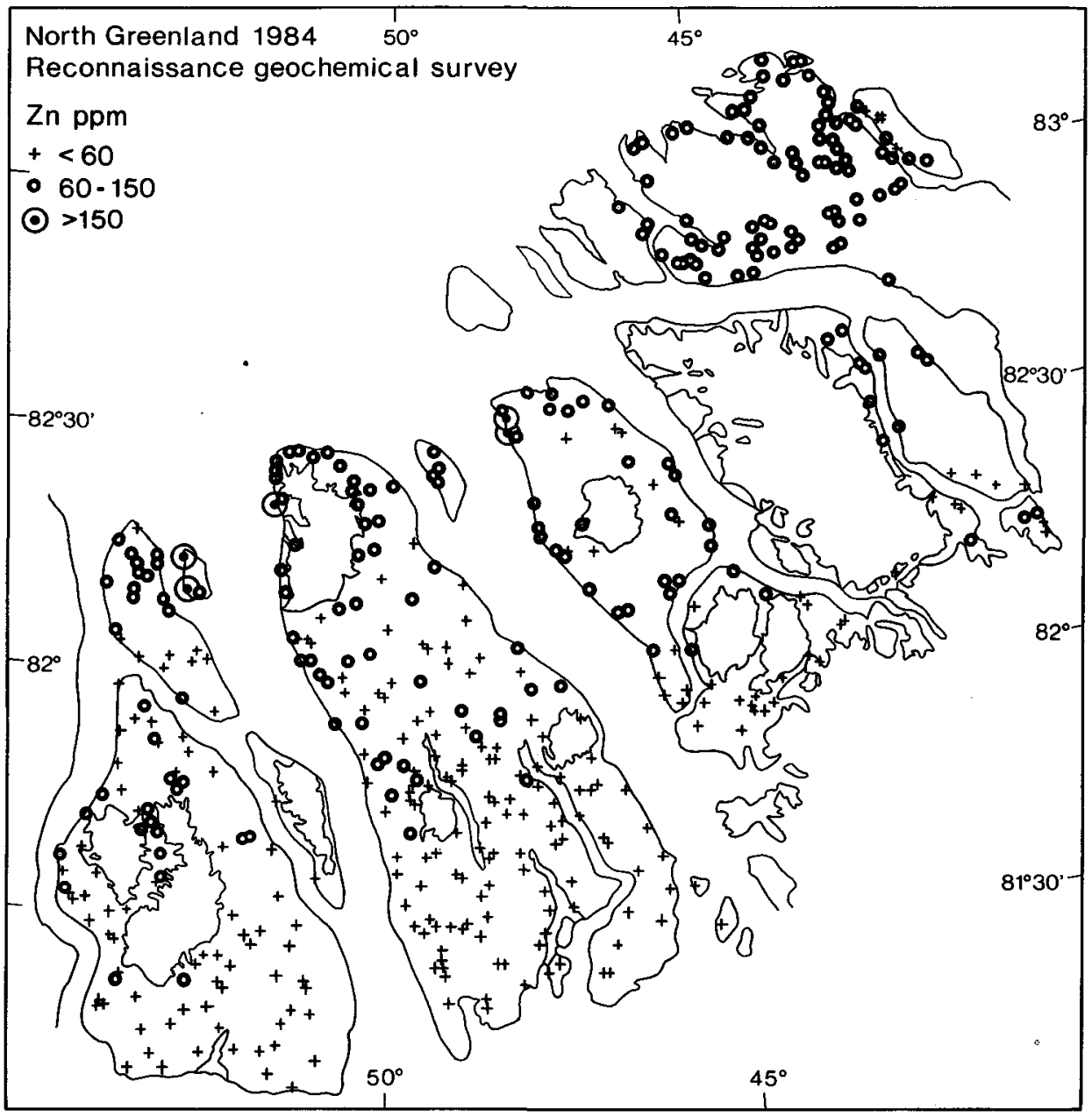

Fig. 4. The regional distribution of the $\mathrm{Zn}$-concentration of the $<0.1 \mathrm{~mm}$ grain size fraction of stream sediment samples.

$\mathrm{Zn}$ and low $\mathrm{BaO}$ and the content of these two elements increases gradually northwards over the platform area. The results of the detailed sampling indicate that $\mathrm{Zn}$ and $\mathrm{BaO}$ are positively correlated in these stratigraphic levels (circles and downwards pointed triangles in fig. 3 ).

The deep-water basin sediments have in general medium to high values of $\mathrm{Zn}$ and $\mathrm{BaO}$, and the highest background values for both elements relate to the Polkorridoren Group of the fold belt in Nansen Land and northernmost Wulff Land. The Paradisfjeld Group, occurring centrally in Nansen Land, appears to have equally much $\mathrm{Zn}$ as the Polkorridoren Group, but somewhat less $\mathrm{BaO}$. 


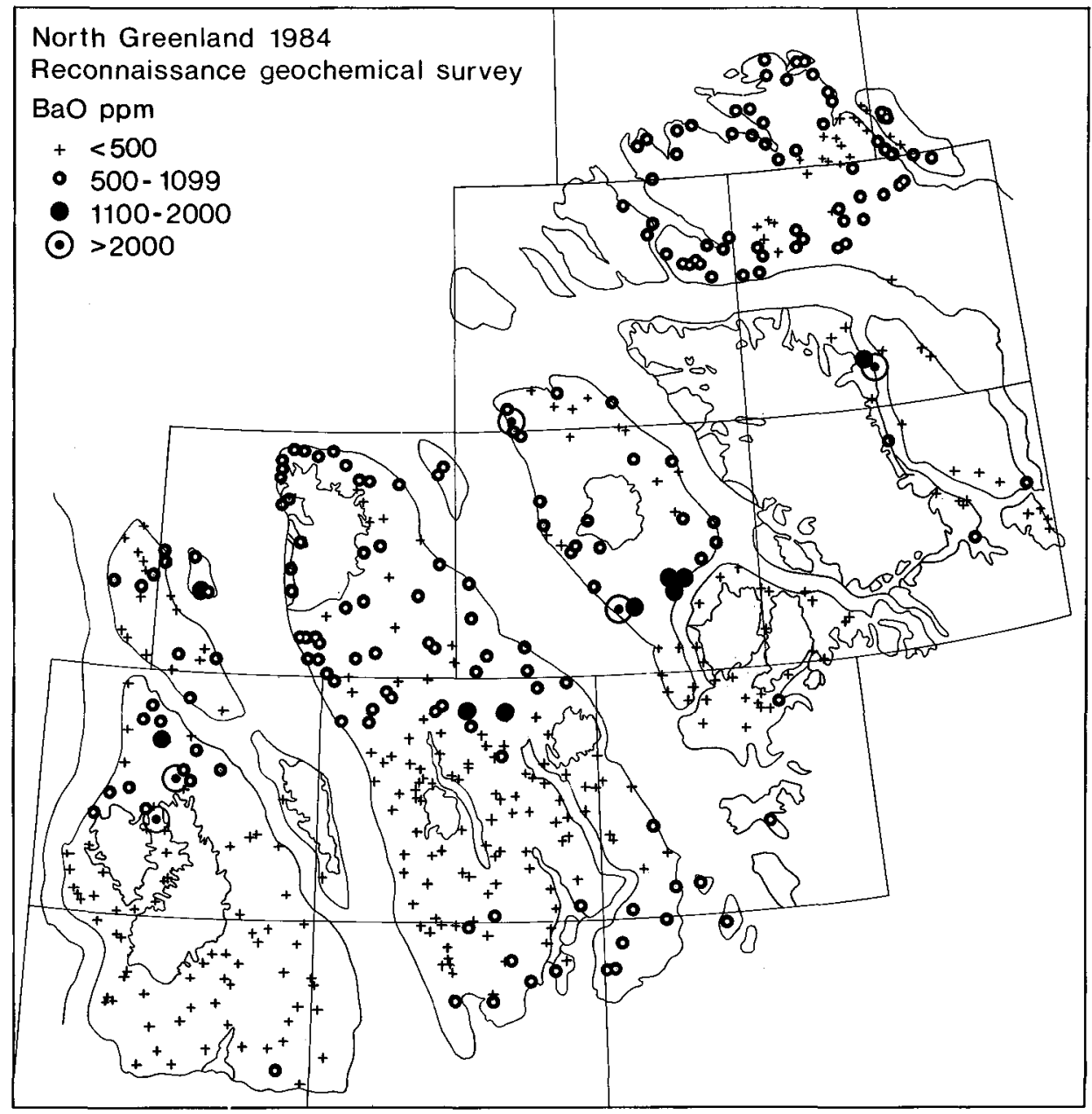

Fig. 5. The regional distribution of the BaO-concentration of the $<0.1 \mathrm{~mm}$ grain size fraction of stream sediment samples.

\section{Anomalous samples}

Based on their character and location, the anomalous samples of fig. 2 (outside the shaded area) can be divided into two groups. One group to the left of the dashed line, with about $100 \mathrm{ppm} \mathrm{Zn}$, and $\mathrm{BaO}$ from $1500 \mathrm{ppm}$ upwards, represents samples located near the main boundary between the platform and the deep-water basin as well as samples from northern Wulff Land (camp 4, fig. 3) and from Navarana Fjord (camp 3, fig. 3). In the two latter areas Cambrian platform strata are brought to the surface through folding and thrusting. The high $\mathrm{BaO}$ content of these samples may reflect the occurrence of a barium-rich lithological unit associated with the platform margin, or it may be indicative of the occurrence of barite.

The other group of anomalous samples to the right of the dashed line in fig. 2 has very 
high $\mathrm{Zn}$ and also high $\mathrm{Ba}$ and their location is shown by ringed dots in fig. 4 (and 5). The final explanation for these anomalous samples must await closer evaluation of all the data. However, calcite-quartz fracture fillings with siderite, occasional galena and sphalerite occur frequently in the flysch sequences, e.g. on Hendrik $\varnothing$ and Castle $\varnothing$, and the anomalies might therefore be indicative of mineralisation in these areas.

\section{Navarana Fjord detailed sampling}

Samples from the detailed sampling at Navarana Fjord (camp 3) fall in three groups in the $\mathrm{Zn}$ versus $\mathrm{BaO}$ diagram (fig. 3). One group plots within the field of background variation (compare fig. 2), one plots in the field of Ba-enrichment mentioned before, and a group of three samples have extremely high values of $\mathrm{BaO}$ and $\mathrm{Zn}$.

Fig. 6 shows the position of the samples on a sketch map of the area. A sphalerite mineralisation (Jakobsen \& Steenfelt, 1985) which is associated with a large vein of calcite is not reflected by high $\mathrm{Zn}$ contents of sediment samples of the nearest stream for topographic reasons.

The most anomalous samples are derived from a small stream draining black dolomitic mudstones of the Cambro-Ordovician un-named starved basin sequence (Higgins \& Soper, 1985). These samples are also anomalous with respect to $\mathrm{Cu}, \mathrm{Cr}, \mathrm{Ni}, \mathrm{P}, \mathrm{S}$ and $\mathrm{V}$. A few (11) rock analyses of the dolomitic mudstone sequence indicate that high contents of $\mathrm{Ba}, \mathrm{Cu}, \mathrm{P}, \mathrm{S}$ and $\mathrm{V}$ are characteristic of parts of this mudstone sequence. Barite was not observed in the field or in the analysed samples. Only one rock sample (without visible zinc minerals) contains $1050 \mathrm{ppm} \mathrm{Zn}$, otherwise the $\mathrm{Zn}$ content of the mudstone samples is below $200 \mathrm{ppm}$.

\section{Zinc mineralisation in relation to tectonic framework}

The two anomalous stream sediment samples from north-west Nares Land (figs 4 \& 5) are also derived from the Ordovician starved basin sequence, and they are very similar in total chemistry to those from Navarana Fjord. Sphalerite was found in the heavy mineral concentrate at this locality. Most of the samples from the detailed sampling in northern Wulff Land (camp 4) in similar lithological units (fig. 3), on the other hand, gave background $\mathrm{Zn}$ and $\mathrm{BaO}$ values, and only 3 samples (out of 24 ) plot together with the group of Ba-enriched samples from Navarana Fjord. In total chemistry the Wulff Land samples from camp 4 resemble the anomalous ones from Navarana Fjord and Nares Land, but lack the enrichment in $\mathrm{Cu}$, $\mathrm{Ni}$ and $\mathrm{Zn}$. A conspicuous $\mathrm{Zn}$ anomaly is, however, noted in the reconnaissance survey, where the starved basin sequence outcrops on the west coast of northern Wullf Land (fig. 5).

The observations suggest that the starved basin sequence, or a section of it, is geochemically different from other slope/basin sedimentary rocks and is characterised by high contents of $\mathrm{Ba}, \mathrm{P}, \mathrm{S}$ and $\mathrm{V}$; however, the fact that the very high $\mathrm{Zn}$ ( $\mathrm{Cu}$ and $\mathrm{Ni}$ ) values are not ubiquitous in relation to this sequence is interpreted as a sign of a mineralising event. It is characteristic that the $\mathrm{Zn}$ anomalies occur where intense tectonic movements affect the starved basin sequence (Soper \& Higgins, 1985).

The sphalerite mineralisation at Navarana Fjord (Jakobsen \& Steenfelt, 1985) occurs in a fault in the Portfjeld Formation and two zinc anomalies on Castle $\varnothing$ can be related to a fault in the Silurian flysch deposits.

The fault related zinc anomalies and zinc mineralisation have a wide regional distribution 


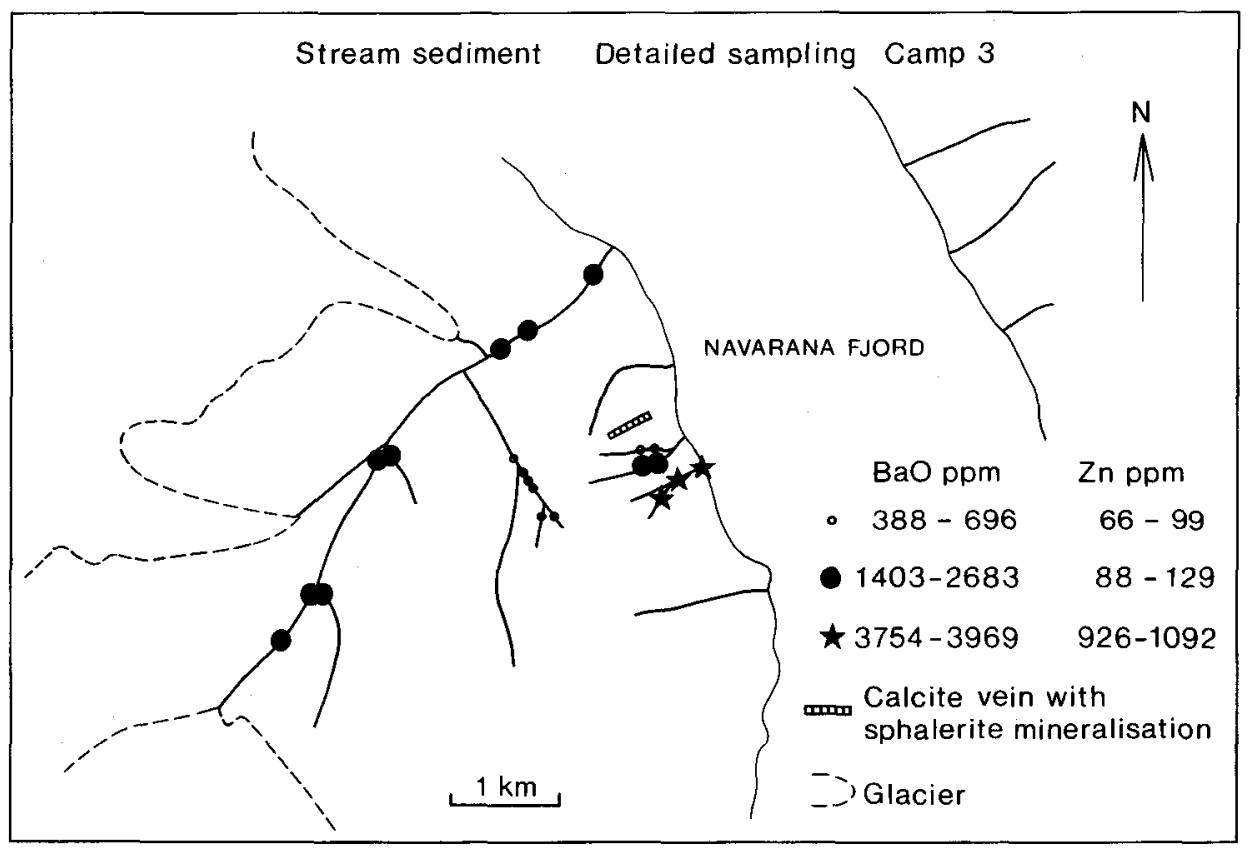

Fig. 6. Zinc and barium contents of stream sediment samples from camp 3. The location of the area is shown in fig. 1.

and occur in host rocks of different ages. However, it is possible that they are all indications of a major zinc mineralising event associated with post-Silurian faulting.

High zinc values $(170-300 \mathrm{ppm})$ in stream sediment from reconnaissance sampling in Peary Land (Steenfelt, 1980; Ghisler \& Stendal, 1980; Henriksen, 1981) are found in an east-west trend along the southern boundary of the fold belt. This trend can be aligned with the east-west trend of zinc anomalies from northern Navarana Fjord, northern Nares Land to northern Wulff Land. However, further evaluation of such large-scale connections must await more studies of the structural and lithological controls of the anomalous localities.

\section{Conclusion}

A comprehensive interpretation of the analytical data of the reconnaissance stream sediment survey comprises statistical treatment and close comparisons of the geochemical pattern with the geology. In this preliminary evaluation, based mainly on the concentrations of $\mathrm{Zn}$ and $\mathrm{Ba}$ in the samples, the following conclusions are made.

The distribution pattern for $\mathrm{Zn}$ and Ba reflects the lithological changes. Lowest values for both elements occur in the lower carbonate platform and the contents gradually increase through upper platform to basin. The Polkorridoren Group of Nansen Land and northernmost Wulff Land has the highest backgrounds for $\mathrm{Zn}$ and $\mathrm{BaO}$.

Barium enrichment is associated with the Silurian platform margin and with the Cambrian-Ordovician platform-slope sequence in Navarana Fjord and north-west Nares Land. 
Zinc anomalies and occurrences of sphalerite are related to faults and may indicate a regional mineralising event.

Acknowledgements. The success of the sampling from helicopter depended heavily on the Heliswiss pilot, Heinrich Zahnd, who is gratefully acknowledged for his skill and encouraging spirit. Ulla Hjorth Jakobsen participated in all phases of the geochemical programme and collected most of the samples.

\section{References}

Bryant, I. D. \& Smith, M. P. 1985: Lowermost Ordovician sandstones in central and western North Greenland. Rapp. Grønlands geol. Unders. 126, 25-30.

Ghisler, M. \& Stendal, H. 1980: Geochemical and ore microscopic investigations on drainage sands from the Peary Land region, North Greenland. Rapp. Grønlands geol. Unders. 99, 121-128.

Henriksen, N. 1981: Collection of samples for a reconnaissance geochemical survey from the Peary Land - Kronprins Christian Land region, North Greenland. Rapp. Grønlands geol. Unders. 106, 8587.

Henriksen, N. 1985: Systematic geological mapping in 1984 in central and western North Greenland. Rapp. Grønlands geol. Unders. 126, 5-10.

Higgins, A. K. \& Soper, N. J. 1985: Cambrian - Lower Silurian slope and basin stratigraphy between northern Nyeboe Land and western Amundsen Land, North Greenland. Rapp. Grønlands geol. Unders. 126, 79-86.

Jacobsen, U. H. \& Steenfelt, A. 1985: Zinc mineralisation at Navarana Fjord, central North Greenland. Rapp. Grønlands geol. Unders. 126, 105-109.

Peel, J. S. \& Wright, S. C. 1985: Cambrian platform stratigraphy in the Warming Land - Freuchen Land region, North Greenland. Rapp. Grønlands geol. Unders. 126, 17-24.

Soper, N. J. \& Higgins, A. K. 1985: Thin-skinned structures of the basin-shelf transition in North Greenland. Rapp. Grønlands geol. Unders. 126, 87-94.

Steenfelt, A. 1980: The geochemistry of stream silt, North Greenland. Rapp. Grønlands geol. Unders. 99, 129-135.

Sønderholm, M. \& Due, P. H. 1985: Lower and Middle Ordovician platform carbonate lithostratigraphy of Warming Land, Wulff Land and Nares Land, North Greenland. Rapp. Grønlands geol. Unders. 126, 31-46. 